\title{
Fiscal Policy Cyclicality and Growth within the U.S. States
}

\author{
By \\ Ayako Kondo \\ and \\ Justin Svec
}

August 2009

\section{COLLEGE OF THE HOLY CROSS, DEPARTMENT OF ECONOMICS \\ FACULTY RESEARCH SERIES, PAPER NO. 09-11*}

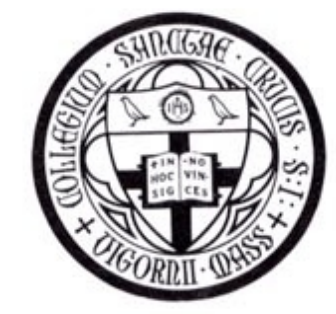

Department of Economics

College of the Holy Cross

Box 45A

Worcester, Massachusetts 01610

(508) 793-3362 (phone)

(508) 793-3710 (fax)

http://www.holycross.edu/departments/economics/website

*All papers in the Holy Cross Working Paper Series should be considered draft versions subject to future revision. Comments and suggestions are welcome. 


\title{
Fiscal Policy Cyclicality and Growth within the U.S. States
}

\author{
By \\ Ayako Kondo ${ }^{\dagger}$ \\ College of the Holy Cross \\ and \\ Justin Svec ${ }^{\dagger \dagger}$ \\ College of the Holy Cross
}

August 2009

\begin{abstract}
We exploit differences in the stringency of balanced budget rules across US states to estimate the effect of fiscal policy cyclicality on state GDP growth. While most states have passed laws restricting deficits, the nature and strictness of these laws vary greatly. States with more stringent balanced budget restrictions run more procyclical fiscal policy. We use the diversity in these laws as an instrument for the cyclicality of state government spending. We find modest evidence that more counter-cyclical public expenditure increases a state's average growth rate per capita. Further, our point estimates suggest that a state could increase its annual growth rate by $0.4 \%$ by relaxing the "ex-post" balanced budget restriction. This estimated effect is statistically significant at the $10 \%$ level in our basic specification, but loses its significance when we control for the initial debt to GDP ratio.
\end{abstract}

JEL Classification Codes: E32, E62, H72

Keywords: growth, fiscal policy, cyclicality

We would like to thank Michael Woodford, Marc Giannoni, Bruce Preston, Alessandra Casella, and John Donaldson for their invaluable support. We owe a lot to Gideon du Rand, who participated in this project at an earlier stage. Our sincerest thanks go to Camelia Minoiu who provided very helpful comments.

${ }^{\dagger}$ Institute for Social and Economic Research, Department of Economics, Osaka University, 6-1 Mihogaoka, Ibaraki, Osaka, Japan, akondo@iser.osaka-u.ac.jp

†'Department of Economics, Box 45A, College of the Holy Cross, Worcester, MA 016102395, 508-793-3875 (phone), 508-793-3710 (fax), jsvec@holycross.edu 


\section{Introduction:}

The recent financial crisis has brought the role of fiscal policy to the forefront of American politics. On February 17th, 2009, President Obama signed an economic stimulus package worth $\$ 789$ billion. The package's combination of fiscal expenditures and tax breaks was largely financed through public debt. The purpose of this stimulus was to "boost economic activity by increasing short-term aggregate demand" (Congressional Budget Office 2008).

Whereas the federal government has the flexibility to run counter-cyclical policy, state governments are more restricted in their options. This is because almost all states (the exception being Vermont) are bound by balanced budget restrictions. To varying degrees of stringency, these rules restrict a state government's ability to run deficits and hence counter-cyclical fiscal policy. One worry is that these constraints might exacerbate the economic downturn. That is, just as private demand has fallen, state governments are forced to reduce their spending and raise taxes to balance their budgets. As Robert Rubin has said, these actions "could turn slowdowns into recessions, and recessions into more severe recessions or even depressions". ${ }^{1}$

This relationship between the cyclicality of fiscal policy and macroeconomic volatility has been extensively analyzed in the empirical literature. Examples include Lane (2003), Levinson (1998), and Sorensen, $\mathrm{Wu}$, and Yosha (2000). Little empirical work, however, has been devoted to studying whether the cyclicality of fiscal policy affects long-run growth. This paper, using US state-level data from $1977-1997^{2}$, examines this topic. Specifically, we seek to answer the following question: does the cyclicality of fiscal policy affect long-run growth within the US states?

One potential channel through which the cyclicality of fiscal policy could affect growth has been identified by Aghion and Howitt (2006). In this model, firms choose to invest in either capital or a productivityenhancing technology. This investment in technology is subject to liquidity shocks that must be covered by each firm. The firms, though, face a credit constraint and can only borrow up to a fraction of their earnings. This constraint implies that recessions reduce the firms' ability to meet the liquidity requirements, forcing them to cut their R\&D investment. As a result, long-run growth slows. The authors suggest that a counter-cyclical fiscal policy could improve growth by relaxing the firms' credit constraint. An example of a policy that accomplishes this goal would be for the government to increase its public investment during recessions. This policy would raise the earnings of the firms, which would ease their credit constraint. This would encourage the firms to invest in the productivity-enhancing technology, raising economic growth. All else equal, this theory implies that states running more counter-cyclical policy should have both lower business cycle volatility and higher growth rates.

\footnotetext{
${ }^{1}$ From "White House Briefing on the Balanced Budget Amendment", 1995.

${ }^{2}$ Our dataset actually extends until 2005, however we limit our time-frame because of changing variable definitions.
} 
This paper explores empirically whether the counter-cyclicality of fiscal policy does indeed promote growth, as indicated by the theoretical literature. Since the cyclicality of policy is a choice variable of state governments, endogeneity is a concern. We exploit the differences in the stringency of balanced budget rules across states as our instrument for cyclicality. These budget restrictions have the potential to affect GDP growth by limiting the state government's ability to run counter-cyclical fiscal policy. The theory discussed above would then imply that states forced to run more procyclical fiscal policy would have lower growth rates on average than those running more counter-cyclical policy.

The balanced budget restrictions, largely implemented before the Civil War, were often enacted as amendments to each state's constitution. Modification therefore requires a public referendum. Further, there is a great deal of variation in the rules across states. In this paper we will consider only one type of variation: whether the proposed budget or the actual budget must be balanced. Some states mandate that either the governor submit or the state legislature enact a balanced budget. These "ex-ante" requirements on the proposed budget are silent about end-of-the-year deficits. The more strict "ex-post" requirement is that the actual budget must be balanced at the end of each fiscal cycle or biennium. These rules typically apply to the general fund, the fund dedicated to operating expenses and discretionary money. The rules do not affect other funds, including the capital, pension, and sinking funds.

To estimate the impact of cyclicality on state growth, we run an instrumental variables regression of growth per capita on our cyclicality measure, instrumenting cyclicality with the balanced budget restrictions. $^{3} \quad$ In the first stage of this analysis, we find strong evidence that the ex-post budget restriction constrains the cyclicality in total spending. That is, a state with the ex-post rule runs a significantly more procyclical policy than a state without the rule. We find no evidence that the ex-ante rule constrains a state's policy options. This differential impact of the ex-post and ex-ante rules is consistent with the findings of Bohn and Inman (1996).

The second stage of our analysis indicates that a more counter-cyclical policy has a modest and positive impact on growth. The point estimate from our basic specification suggests that a state can increase its growth by $0.4 \%$ per year by relaxing the ex-post budget restriction. This estimated effect is statistically significant at the $10 \%$ level. The sign and size of this coefficient are consistent even after controlling for initial population, political variables, and Federal transfers to the state governments. However, the statistical significance is reduced when we add the initial debt level as a control variable.

The result that a more counter-cyclical policy increases growth is reminiscent of Aghion and Marinescu (2007), the analysis closest to ours in theme if not approach. That paper examines the growth impact of cyclicality across OECD countries. Exploiting a panel dataset, the authors study the dynamic effects of

\footnotetext{
${ }^{3}$ Because the restrictions were enacted so long ago, we cannot exploit the timing of the rule introduction. Consequently, our IV regressions are all cross-sectional tests.
} 
cyclicality. There are a number of differences between their paper and ours. First, our analysis exploits the variation in balanced budget rules as an instrument for cyclicality whereas they use lagged cyclicality. This difference allows us to make more of a causal argument that cyclicality affects growth, even though it limits our ability to assess the dynamic effects.

Second, our focus is entirely on the US states rather than OECD countries. This focus yields more consistently defined and measured variables. Furthermore, the institutional environment (monetary policy and trade openness, for example) is more similar across states than across OECD countries. One potential disadvantage of examining state-level data is the worry that a state's fiscal policy might not be local enough to affect that state's growth rate. However, the findings of Besci (1996) and Yamarick (2000) suggest that states can indeed influence their growth rates through their policy choices.

In section 2, we describe the data and general properties of both state fiscal policy and the balanced budget rules. In section 3, we characterize our estimation technique. Section 4 discusses our results and extensions, and section 5 concludes.

\section{Data:}

Yearly data on the gross domestic product by state was obtained from the website of the US Bureau of Economic Analysis. The BEA also provided (through the US Government Printing Office) the data on the GDP deflator. Our sources of information for the balanced budget rules are the National Conference of State Legislatures and Bohn and Inman (1996).

Data on state and local total expenditures, current operations, capital outlays, total debt, and intergovernmental transfers are from the US Department of Commerce and the Census Bureau. We use data for the years $1977-1997 .^{4}$ Because state governments often delegate their fiscal responsibilities to local governments in an effort to evade the balanced budget requirements, we use the sum of state and local expenditures as our measure of "state expenditures". ${ }^{5}$

To control for voter preferences, we have obtained two political variables from the National Governors Association website. The first is the political party to which each governor belonged in $1977 .{ }^{6}$ The

\footnotetext{
${ }^{4}$ Even though the dataset includes annual statistics from 1977-1999 and biannual statistics from 2001 to 2005 , we limit ourselves for a number of reasons. First, and most importantly, the approach used to measure gross domestic product by state switched in 1997 from SIC to NAICS. By limiting our time frame, we are using only consistently measured data. Second, in 2001, the Census Bureau stopped collecting state and local government data annually, limiting the value of extending the time frame.
}

${ }^{5}$ We test this inclusion for robustness by not including the local statistics. This deviation does not qualitatively change our results. We report these findings in Table A4 in the appendix.

${ }^{6}$ Every state except Maine had a governor that belonged to either the Democratic or Republican parties in $1977 . \quad$ Maine 
second is the number of times the political party of the governor has switched over the time frame of our analysis. This second variable is meant to capture the voracity effect, highlighted by Lane and Tornell (1996). This effect suggests that a greater degree of political competition increases the cyclicality of fiscal policy because each party has the incentive to spend its available resources, since they would lose access to the funds if the other party is elected. Finally, we have data on both the level of education and population across states in 1977 .

States, unlike the federal government, practice fund accounting. This means that all revenues and expenditures are designed specifically to enter and leave a particular fund. This practice is a vestige from the 19th century when states did not have a unified budget. Examples of funds include the capital fund, which allocates capital borrowings; the sinking fund, which directs money to debt repayment; and the pension fund, which collects money for state employee retirement. One of the most important funds is the general fund. The general fund receives between $50-60 \%$ of all state revenue and finances most legislative expenditures. The majority of a state's discretionary budget comes from this fund.

Balanced budget restrictions typically apply to the general fund. Because of this, a considerable portion of a state's spending is affected by the balanced budget rules. The National Conference of State Legislatures has estimated that, in more than two-thirds of all states, at least $75 \%$ of a state's spending is affected by the rules. Further, at least $25 \%$ of expenditures are affected by the rules in 48 states.

There are numerous types of these balanced budget restrictions across states. Some states require that the governor's proposed budget is balanced. Others mandate that the budget passed by the state legislature is balanced. We label these restrictions "ex-ante" because the rules explicitly constrain only the forecasted budget. The most strict budget rule requires that the actual budget is balanced at the end of each fiscal year or biennium. This "ex-post" restriction implies that a state cannot run a deficit in their general fund. In Figure 1, we have drawn a map that displays which states have the ex-post restriction. As can be seen, the states that have the ex-post law are more likely to be small.

had an Independent governor. 


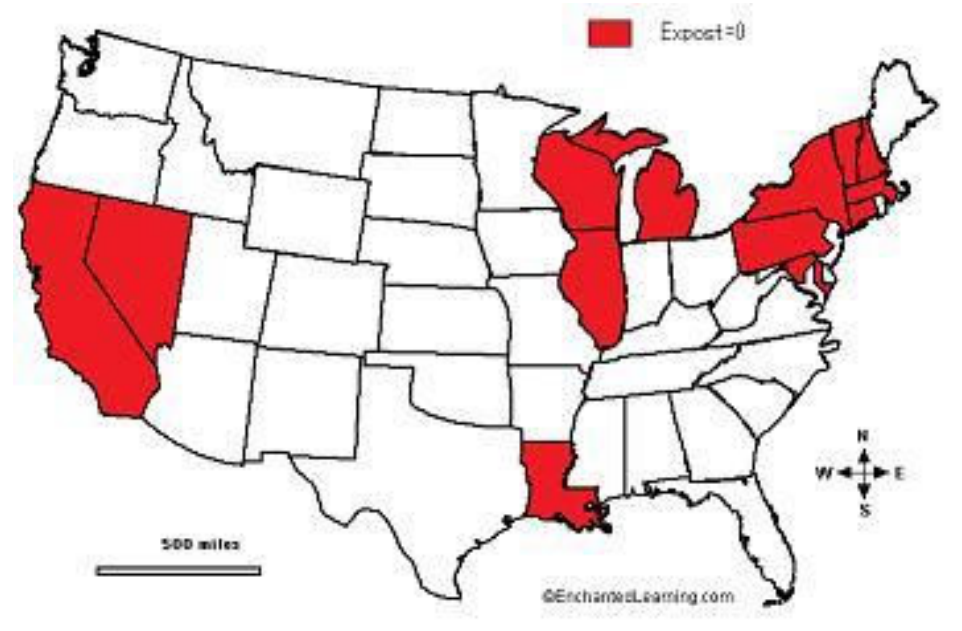

Figure 1: States without ex-post rules in red

The Advisory Commission on Intergovernmental Relations (1984) summarized the stringency of the balanced budget restrictions in an index scaled 0 to 10. This index, labeled ACIR, gives a 0 to states with the least stringent requirements and a 10 to states with the most stringent. Two-thirds of states were given an 8 or higher, and only three states were given scores below 4 . Our analysis uses the ex-ante and ex-post rules as well as the ACIR index as potential instruments for cyclicality.

The majority of these rules were enacted as amendments to the state's constitution following the Panic of 1837. Between 1835 and 1837, private banks multiplied and credit expanded quickly. Investors used the credit to buy land west of the Mississippi River from the federal government. The Treasury Department tried to curb this credit growth by issuing "Specie Circular" in 1836, which stipulated that all federal land transactions must be made in specie. As a result, "the nation's complex and interwoven system of credit tumbled like a house of cards. Specie fled the Eastern states to accommodate land transactions in the West, leaving Eastern business and Southern agriculture to wither on the financial vine" (Savage 1988). The Panic of 1837 ensued. During this period state tax revenue fell dramatically, forcing states to run large deficits. The financial condition of states deteriorated to such a degree that numerous states defaulted, including Florida, Indiana, Illinois, Louisiana, Michigan, and Pennsylvania. Many others were on the brink of default.

Politicians blamed the budget problems on the surpluses generated by the tariff of 1828 , which encouraged excessive state spending. This prompted a movement to impose balanced budget constraints on state governments. The purpose of these measures was to constrain legislative spending and prevent debt from crippling state governments. Rhode Island, debt-free at the time, was the first state to adopt the restriction in 1842. Its lead was quickly followed by others. ${ }^{7}$ In Table 1, we have listed the year that

\footnotetext{
${ }^{7}$ Many states adopted balanced budget restrictions similar to New Jersey's, another debt-free state. This provision states
} 
each state adopted the balanced budget rule.

These balanced budget rules have persisted until today, discouraging states from running deficits in their general fund. Now, when states face a budget shortfall, they can respond by raising taxes, reducing expenditures, or with varying ability, going into debt. In addition to these standard actions, states could resort to budget gimmicks. These gimmicks include pushing fiscal responsibilities onto local governments and altering the state's accounting standards. These manipulations obviate the states' need to abide by their balanced budget rules. Our analysis accounts for the first gimmick by including both local and state government finances in our empirical work. Further, the Government Accountability Office suggests that the second gimmick is used only rarely. In fact, the GAO estimates that $49 \%$ of a budget shortfall is closed through spending reductions, $32 \%$ by increases in taxes, and only the remaining $19 \%$ by budget gimmicks.

Table 2 shows summary statistics of the states' characteristics, broken down by whether the state has the ex-post rule. The average nominal and real GDP growth rates across all states from 1977 - 1997 is $6.1 \%$ and $1.9 \%$, respectively. The average growth rate is slightly higher in states without the ex-post rule, although the difference is not statistically significant. The average total expenditure as a percentage of the state's GDP is $17.3 \%$. Out of this total spending, $72 \%$ goes to financing current operations and $13 \%$ goes to capital outlays. There are not significant differences between states with and without the ex-post rule, except that those with the ex-post rule tend to spend larger fractions of expenditure on capital outlays. The characteristics in 1977 indicate that states without the ex-post rule were on average larger and richer.

\subsection{Cyclicality Measure:}

The goal of our analysis is to estimate the growth impact of fiscal cyclicality. To derive our measure of cyclicality, we follow the literature and use a regression-based approach. This type of approach can be seen in Alesina and Tabellini (2005) and Lane (2003). Our measure estimates the relationship between a change in output and a change in government expenditure, controlling for inflation. We also include a state-specific time trend. That is, for each state and using data from 1977 to 1979, we run the following regression:

$$
\Delta \log G_{s t}=\alpha_{1, s}+\alpha_{2, s} \Delta \log Y_{s t}+\alpha_{3, s} \pi_{t}+\alpha_{4, s} t+\epsilon_{s t}
$$

where $G_{s t}$ is the level of state government expenditure in state $s$ at time $t, Y_{s t}$ is the per-capita level of gross domestic product in state $s$ at time $t$, and $\pi_{t}$ is the change in the GDP deflator at time $t$. This rate of inflation applies to all states. Thus, for a given level of inflation, the time-invariant coefficients $\alpha_{2, s}$

\footnotetext{
"The legislature shall not, in any manner, create any debt or debts ... which shall singly or in the aggregate ... exceed one hundred thousand dollars, except for purposes of war ... unless the same shall be authorized by a law for some single object or work, to be distinctly specified therein".
} 
measure the degree of comovement between the growth of state government expenditure and the growth in the state's gross domestic product. The estimated $\alpha_{2, s}$, denoted $c y c_{s}$, serves as our measure of fiscal cyclicality in state $s .^{8}$

With this formulation, the average cyclicality across states is -0.14 . This means that states, on average, run a counter-cyclical fiscal policy, increasing government spending when output falls. There is a great deal of diversity across states, though. The level of cyclicality in the most pro-cyclical state (Hawaii) is 0.66 , while in the most counter-cyclical state (Florida), the level of cyclicality is -1.04. Appendix Table A1 presents the estimated cyclicality for each state.

To get a better sense of these averages, we decompose total public expenditure into its component parts. We then insert each of these smaller categories into (1) to determine the cyclicality of each component. Table 3 details the average estimated cyclicality of these components of public expenditure across all states. We further list how the estimated cyclicality varies by type of balanced budget restriction. As is shown, health care expenditure is the most counter-cyclical component of public expenditure. States without the ex-post restriction, though, implement a signficantly more counter-cyclical health care policy than states with the restriction. This observation highlights a more general trend: across all listed categories, the estimated cyclicality is more negative in states without the ex-post rule than in states with the rule. Finally, capital outlays are the only listed component of public expenditure that is procyclical for both groups of states. ${ }^{9}$

\section{Estimation:}

To determine the impact of fiscal policy cyclicality on real per capita growth, we estimate the following cross-section growth regression:

$$
\stackrel{-}{\log } Y_{s}=\beta_{1}+\beta_{2} c y c_{s}+\beta_{3} X_{s}+\nu_{s}
$$

where $\Delta \log Y_{s}$ is the average growth rate in the per capita real GDP by state for the period of 19771997, cyc $_{s}$ is the measure of cyclicality by state that we derived above, $X_{s}$ is a vector of other covariates, and $\nu_{s}$ is a random error term. In our basic regression, $X_{s}$ includes the initial levels of education and

\footnotetext{
${ }^{8}$ One potential criticism of this measure of cyclicality is that we are not accounting for the feedback between public spending growth and output growth. This would mean that our measure of cyclicality is biased. However, as long as the bias is uncorrelated to the stringency of the balanced budget restrictions (or even constant across states), then our IV analysis should correctly identify the impact of cyclicality on growth. This is because we exploit the variation in the balanced budget restrictions as a source of exogenous movement in cyclicality.

${ }^{9}$ It should be noted that capital outlays are not directly affected by the balanced budget requirements. This is because capital outlays come from a capital fund and not the general fund. We have confirmed that excluding capital outlays from our analysis does not change our results.
} 
income in 1977. In our fuller regressions, we include two political variables and the initial levels of population, Federal transfers, and the total debt to GDP ratio in each state. The coefficient of interest is $\beta_{2}$, the estimated effect of cyclicality on per capita growth.

Endogeneity is likely to be a concern in this regression, since a state government could alter its spending habits in response to a recession, for example. Ordinary least squares therefore would produce a biased estimate of $\beta_{2}$. To account for this endogeneity, we instrument our measure of fiscal cyclicality with state balanced budget restrictions. Our hypothesis is that balanced budget rules impinge upon the state government's ability to run counter-cyclical policy, and this, in turn, affects the state's growth rate per capita. The exclusion restriction is that, given the control variables, balanced budget rules do not affect growth directly.

One potential criticism of our approach is that the type of balanced budget rule implemented by each state may reflect the voters' taste for deficits. These preferences then may be correlated to other variables related to growth. We attempt to control for this by including the political variables as explanatory variables. But, there is a deeper reason that leads us to believe that this endogeneity is not plaguing our results. The balanced budget rules were largely enacted from 1842 to the outbreak of the Civil War as an amendment to the state's constitution. This made it challenging for a state to modify the restriction, since modification requires a public referendum. An indication of this difficulty is that no state within the last 30 years has modified their balanced budget rules. Thus, there is an element of historical legacy to these restrictions. Then, if voter preferences over deficits, for example, have changed over time, this change was not reflected in changing the balanced budget rules. If this is the case, the rules can be taken as exogenous. A similar argument is made in Poterba (1996).

The first stage of our two-stage least squares approach estimates the impact of the balanced budget restrictions on our measure of fiscal cyclicality:

$$
c y c_{s}=\gamma_{1}+\gamma_{2} B B R_{s}+\gamma_{3} X_{s}+v_{s}
$$

where $B B R_{s}$ is the type of balanced budget rule in state $s$. To be clear, when we use the ex-ante or ex-post rule as the instrument for cyclicality, $B B R_{s}$ is a dummy variable that takes a 1 if the state has

the rule and 0 otherwise. When we use the ACIR index as the instrument, though, $B B R_{s}$ takes on the value that each state is given in the index.

\section{Results:}

This section reports our empirical results. The main regressions presented below use total government expenditure as our variable of fiscal policy. 
OLS Results: Table 4 reports the ordinary least squares regression of (2) under four specifications. The first column, our most basic regression, includes inital income and education as controls. The other columns augment the list of covariates with population and political variables, intergovernmental transfers, and the initial debt to GDP ratio. Across these specifications, the coefficient on cyclicality remains zero and never statistically significant. If cyclicality were exogenous, these regressions would imply that growth was unrelated to the cyclicality of fiscal policy. However, it is likely that these regressions are misspecified, since cyclicality is a choice variable of state governments. In the next section, we instrument the cyclicality of fiscal policy with each state's balanced budget rule.

IV Results: Assuming that the balanced budget rules are indeed exogenous, our instrumental variables approach should provide an unbiased estimate of the effect of fiscal cyclicality on growth. The first stage of this empirical strategy is to determine the impact of the balanced budget rules on the degree of cyclicality in total expenditure. Table 5 presents these results. If the restrictions constrain a state's ability to run counter-cyclical fiscal policy, we would expect a positive coefficient on $B B R_{s}$.

The results suggest that the ex-post balanced budget rule significantly increases fiscal cyclicality. In fact, the estimated effect of this balanced budget rule is quite constant across a variety of specifications. The cyclicality of total expenditure in states with the ex-post rule is approximately 0.25 higher than in states without the rule. Put another way, states that are bound by the ex-post balanced budget rule run a total expenditure policy that is two-thirds of a standard deviation more procyclical than states that do not. A similar result holds when using the ACIR index as the instrument: states with higher scores on the ACIR index have more procyclical policies. The coefficients are even consistent with those from the ex-post regression. This is because, on average, states with the ex-post restriction score 5 points higher on the ACIR index than states without the restriction. We have plotted the cyclicality of state fiscal policy against the ACIR index in Figure 2. This figure indicates that the only states that run procyclical policies are those with ACIR index values of at least 8 . 


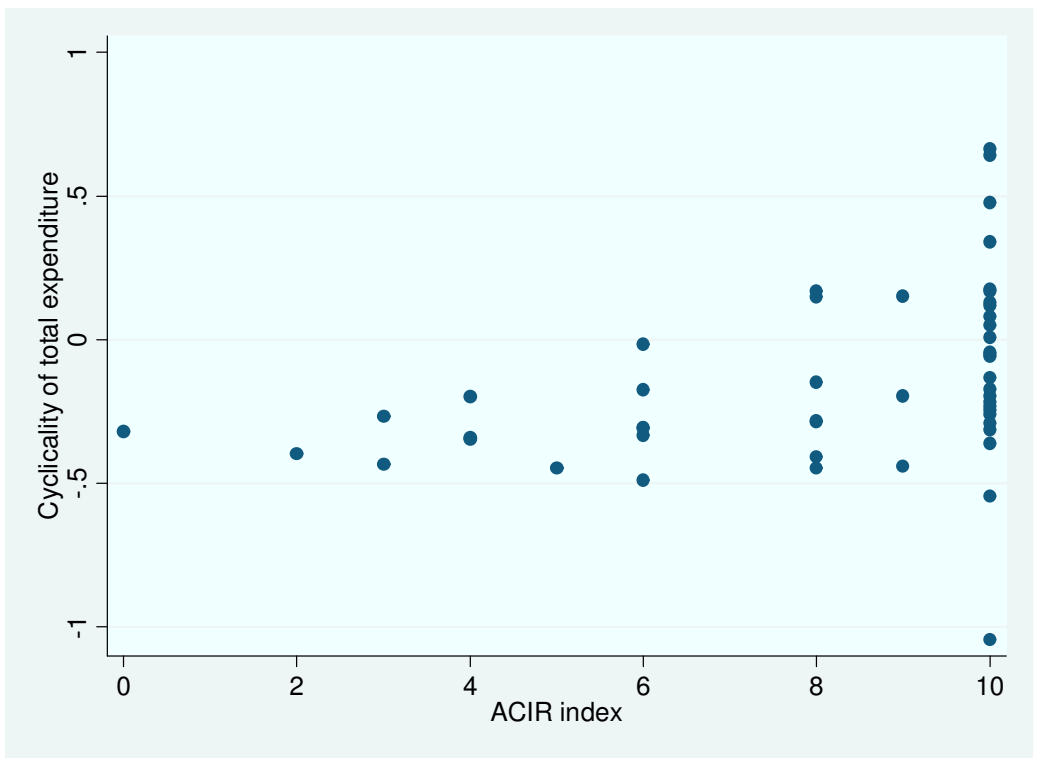

Figure 2: Plot of estimated cyclicality on ACIR index

Also, the last column of Table 5 suggests that the ex-ante balanced budget rule does not significantly affect the cyclicality of policy. These conclusions are redolent of Bohn and Inman (1996), who find that the ex-post rule constrains a state's ability to run deficits, while the ex-ante rule does not ${ }^{10}$.

Because the ex-ante restriction does not affect cyclicality, the rest of the analysis uses the ex-post rule and ACIR index as instruments. Table 6 reports the results from the second stage estimation. Columns 1 and 2 present our basic regressions with initial income and education as explanatory variables. The difference between the two columns is the choice of instrument: we use the ex-post rule in the first column and the ACIR index in the second. Columns $3-8$ augment our basic regressions with the additional explanatory variables of initial population, political party, Federal transfers, and the debt ratio.

As seen from Table 6, the sign of the coefficient measuring the impact of cyclicality on growth is negative across all specifications. Whereas the OLS regressions indicated that there was no relationship between cyclicality and growth, the instrumental variables analysis suggests that a more counter-cyclical fiscal policy increases growth. This result is consistent with Aghion and Howitt (2006), which implies that a more counter-cyclical policy enhances growth.

Although the coefficient on cyclicality is consistently negative, it is statistically significant at the $10 \%$ level only in columns 2, 4, and 6. These columns exploit the ACIR index as the instrument for cyclicality. Using the ex-post balanced budget rule as the instrument, however, slightly lowers the coefficient and

\footnotetext{
${ }^{10}$ One potential explanation for this fact is that the ex-ante balanced budget rule applies only to the expected budget, while our dependent variable is the actual expenditure of the government. This mismatch might imply that the ex-ante rule is insignificant when, in fact, it actively constrains the expected budget.
} 
increases the standard errors, nudging the significance outside of the $10 \%$ threshold. This leads us to believe that the positive impact of counter-cyclicality on growth is modest.

The magnitude of the coefficient on cyclicality is fairly consistent across columns $1-6$. Controlling for initial population, political variables, and Federal transfers to states does not alter the estimated impact of cyclicality. Including the initial debt to GDP ratio as an explanatory variable, though, reduces the cyclicality coefficient's magnitude. ${ }^{11}$ Put in terms of a policy prescription, our point estimate suggests that a state government could increase its average annual growth by $0.4 \%$ if it relaxes the ex-post balanced budget rule. This effect is statistically significant at the $10 \%$ level in our basic specification and moves slightly outside of this threshold after including the political, population, and intergovernmental transfer variables. This result can be seen in Table 7 .

We draw two main conclusions from these basic regressions. First, states with the ex-post balanced budget restriction implement policy that is significantly more procyclical than states without the restriction. The same result holds for states that have higher ACIR index values. It seems, though, that the ex-ante budget rule does not constrain a state government's ability to run counter-cyclical policy. Second, we find that a more counter-cyclical fiscal policy has a modest, yet positive impact on growth. The estimated coefficient suggests that a state can increase its growth rate by approximately $0.4 \%$ per year if it relaxes the ex-post balanced budget restriction. This result, while significant at the $10 \%$ level in our basic specification, loses its statistical significance after controlling for the states' initial debt to GDP ratio.

Our conclusions are related to the findings of Aghion and Marinescu (2006). In their panel data estimation across OECD countries, they also find that a more counter-cyclical fiscal policy has a positive impact on growth. Their result holds under a variety of definitions of cyclicality and fiscal expenditure. However, their work suggests that, although the majority of OECD countries would benefit from making their policies more counter-cyclical, this is not the case for the United States. Instead, the US federal government could increase the growth rate by implementing a more procyclical fiscal policy. There are a number of possible reasons why our analysis draws the opposite conclusion. First, our analysis explores the impact of state fiscal cyclicality and not the nation as a whole. It could well be that state governments should respond differently to the business cycle than should the federal government, given that they have different spending responsibilities. Second, we exploit the variation in balanced budget restrictions as

\footnotetext{
${ }^{11}$ This implies that the initial debt ratio is correlated with the balanced budget rule. If the debt ratio in 1977 is related
} to some factor that affected the stringency of the adopted balanced budget rule, then our instrument is not exogenous. However, it seems plausible to us that the direction of causality goes in the opposite direction: the balanced budget rules, often implemented before the Civil War, partially determine the debt ratio in 1977. This belief could help explain the positive coefficient on the initial debt ratio. If taken at face value, this sign would yield the counter-intuitive conclusion that, ceteris paribus, a higher level of initial debt increases state per capita growth. Rather, it seems more reasonable that the balanced budget rules shape a state's flexibility to implement counter-cyclical policy which, in turn, affected their debt levels in 1977. 
an instrument for cyclicality, while Aghion and Marinescu (2006) use lagged cyclicality directly in their growth regressions. This discrepency could lead to different estimates, depending on the quality of the instruments.

Decomposing Expenditure: Table 3 has established two key facts. First, the cyclicality of different components of total expenditure varies substantially. Second, for a given category of expenditure, there are large differences in the mean level of cyclicality across states with and without balanced budget restrictions. This section explores these issues more closely, examining the effectiveness of the balanced budget restrictions at constraining the cyclicality of numerous components of total expenditure. To do this, we estimate (3) for each category of public expenditure listed in Table 3; the results are reported in Table 8.

Table 8 suggests that states with the ex-post balanced budget rule run a significantly more procyclical current operations policy than states without the rule. In fact, across all expenditure categories, the coefficients on the ex-post balanced budget rule and the ACIR index are positive. The relative sizes of the coefficients further indicate that states with balanced budget rules cut health care spending more in recessions than they cut the salaries and wages of public employees. However, except for in the case of current operations, these coefficients are not statistically significant at the $10 \%$ level.

Volatility Extension: The above sections establish a connection between the cyclicality of fiscal policy and growth. One natural extension of this analysis is to examine the determinants of output volatility. Thus, we now turn to the following question: How does the cyclicality of fiscal policy affect output volatility?

Following the literature, we will define two measures of output volatility by state. The first measure is the standard deviation of each state's annual growth rates from 1977 - 1997. This measure was used, for example, in Fatas and Mihov (2006). The second measure defines output volatility as the difference between each state's maximum growth rate and its minimum. These measures of output volatility are then regressed on cyclicality and other control variables through the following equation:

$$
\text { volatility }_{s}=\delta_{1}+\delta_{2} c y c_{s}+\delta_{3} X_{s}+\eta_{s}
$$

For simplicity, we control only for initial income and education.

As in the previous sections, one potential problem with this regression is the endogeneity of fiscal policy. That is, a state government might alter the cyclicality of its fiscal policy depending on that state's output volatility. To correct for this, we instrument cyclicality with the ex-post balanced budget rule and the ACIR index discussed above. The results from this IV analysis are reported in Table 9. Across all specifications, the coefficient on cyclicality is positive. This point estimate would seem to imply that a 
more procyclical fiscal policy increases the volatility of output. This sign is consistent with the theoretical channel described in Aghion and Howitt (2006). However, regardless of the instrument used and the measure of volatility, cyclicality is never statistically significant at the $10 \%$ level.

\section{Conclusion:}

This analysis examines the impact of fiscal cyclicality on state growth per capita. Because cyclicality is potentially endogenous, we use the variation in the stringency of balanced budget restrictions across states as an instrument for cyclicality. We find that states with strict balanced budget requirements, as summarized by the ACIR index, run significantly more procyclical expenditure policies. In particular, states that have a constitutional amendment restricting ex-post deficits in the general fund run policies that are two-thirds of a standard deviation more procyclical than states that do not. This result is intuitive, since states with strict balanced budget requirements are forced to reduce their spending during recessions, so as to avoid running deficits. The coefficient describing this effect is significant at the $1 \%$ level across a variety of specifications.

We then regress state growth per capita on cyclicality, using the results from the first stage regression. We find that policies that induce more counter-cyclical total expenditures have a modest, yet positive effect on growth. If taken at face value, one policy implication of this work is that a state can increase its annual growth rate by $0.4 \%$ by relaxing the ex-post balanced budget requirement. This effect is statistically significant at the $10 \%$ level in our basic specification but loses its significance when we control for the initial debt to GDP ratio in each state. Qualitatively, this result remains essentially unchanged when we examine a state government's current operations rather than total expenditures.

Finally, we consider two extensions. First, we explore how the balanced budget rules affect the cyclicality of different components of public expenditure. This section finds that states with strict balanced budget rules run more procyclical current operations and health care policies than states without the rule. Second, we explore whether the cyclicality of fiscal policy affects output volatility across states. This test could potentially indicate the channel through which the cyclicality of fiscal policy affects growth. We show that the point estimate on cyclicality in these regressions is positive, matching the theoretical implications, but that the effect is never statistically significant at the $10 \%$ level. Thus, cyclicality does not seem to affect growth by influencing business cycle volatility, at least across the US states.

We conclude by highlighting one possible route for future research. The current analysis studies whether the cyclicality of fiscal policy promotes growth within the US states, using aggregate variables like total expenditure as our measure of fiscal policy. In our future work, we plan to decompose this measure to determine which components are most effective at spurring growth. 


\section{References}

1. Acemoglu, Daron; Simon Johnson; and James Robinson, 2001. "The Colonial Origins of Comparative Development: An Empirical Investigation." The American Economic Review 91, 1369-1401.

2. Advisory Commission on Intergovernmental Relations (ACIR), 1987. Fiscal Discipline in the Federal System: Experience of the States.

3. Advisory Commission on Intergovernmental Relations (ACIR), 1995. Significant Features of Fiscal Federalism.

4. Aghion, Philippe and Peter Howitt, 2006. "Appropriate Growth Policy: A Unifying Framework." Journal of the European Economic Association 4, 269-314.

5. Aghion, Philip and Ioana Marinescu, 2007. "Cyclical budgetary policy and growth: what do we learn from OECD panel data?", Macroeconomics Annual 22, 251-278.

6. Besci, Zsolt, 1996. "Do State and Local Taxes Affect Relative State Growth?" Atlanta Federal Reserve Bank Economic Review, 18-35.

7. Bohn, Henning and Robert Inman, 1996. "Balanced Budget Rules and Public Deficits: Evidence from the U.S. States." Carnegie-Rochester Conference Series on Public Policy 45, 13-76.

8. Congressional Budget Office, 2008. "Options for Responding to Short-Term Economic Weakness." Testimony by Peter Orszag.

9. Fatas, Antonio and Ilian Mihov, 2006. "The Macroeconomic Effects of Fiscal Rules in the U.S. States." Journal of Public Economics 90.

10. Fatas, Antonio and Ilian Mihov, 2002. "Government Size and Automatic Stabilizers: International and Intranational Evidence." Journal of International Economics.

11. Heins, James, 1963. Constitutional Restrictions Against State Debt. The University of Wisconsin Press.

12. Lane, Philip, 2002. "The Cyclical Behaviour of Fiscal Policy: Evidence from the OECD." Journal of Public Economics, 87, 2661-2675.

13. Levinson, Arik, 1998. "Balanced Budgets and Business Cycles: Evidence from the States." National Tax Journal LI.

14. National Association of State Budget Officers (NASBO), 1989. Budget Processes of the States. 
15. Poterba, James, 1994. "State Responses to Fiscal Crises: The Effects of Budgetary Institutions and Politics." Journal of Political Economy 102, 799-821.

16. Poterba, James, 1996. "Budget Institutions and Fiscal Policy in the U.S. States." American Economic Review: Papers and Proceedings 86, 395-400.

17. Ramey, Garey and Valerie Ramey, 1995. "Cross-Country Evidence on the Link Between Volatility and Growth." The American Economic Review 85 (5), 1138-1151.

18. Savage, James, 1988. Balanced Budgets and American Politics. Cornell University Press.

19. Smith, Daniel and Yilin Hou, 2008. "State Spending Behavior Under Heterogenous Balanced Budget Requirement Systems: A Long-Panel Study." Working paper.

20. Sorensen, Bent; Lisa Wu; and Oved Yosha, 2001. "Output Fluctuations and Fiscal Policy: U.S. State and Local Governments1978-1994." European Economic Review 45, 1271-1310.

21. Yamarick, S. 2000. "Can Tax Policy Help Explain State-Level Macroeconomic Growth." Economic Letters 68, 211-15.

\section{Appendix}

Robustness Checks: We run a variety of alternative specifications to our basic IV analysis to check for robustness. For example, a number of papers that examine fiscal policy across states, including Levinson (1998) and Fatas and Mihov (2002), drop both Alaska and Hawaii from their empirical formulation. This is because both states have unique fiscal environments. Alaska, for example, is unique because of the large revenues generated from severance taxes on oil. As a robustness check, we run our same IV method excluding these two states. The coefficient on cyclicality remains negative and of similar magnitude to our main regressions, although the statistical significance is slightly reduced. These findings are reported in the appendix in Table A2.

Another variation we try is to redo our analysis using current operations as our measure of fiscal policy rather than total expenditure ${ }^{12}$. The results from this variation are largely similar to our main analysis. The first stage of our IV method indicates that states with higher ACIR index values run significantly more procyclical policies than states with lower values. This coefficient is significant at the $1 \%$ level. The coefficient on the ex-post budget rule remains positive but loses its statistical significance. The results from the second stage are reported in Table A3. We have reported only the results using ACIR as the

\footnotetext{
${ }^{12}$ We also redid our analysis using current expenditures as our measure of fiscal policy. The results are essentially the same as for total expenditures, so we suppress this table in favor of reporting the results using current operations.
} 
instrument for cyclicality. Table A3 indicates that counter-cyclical spending on current operations has a positive effect on growth, although this effect is statistically significant at the $10 \%$ level only in our most simple regression. Including initial population, political variables, and Federal transfers to states as additional controls does not seem to change the result much, but it does slightly raise the standard errors. Adding the initial debt ratio, though, markedly decreases the coefficient's magnitude.

A third variation checks the robustness of including both local and state government finances in our measure of total expenditures. We do this by considering only state government expenditures. We find that our conclusions are essentially unchanged from our main regressions. The first stage of our IV analysis suggests that both the ex-post rule and the ACIR index are significantly correlated to the cyclicality of fiscal policy. Then, in our second stage growth regression, all coefficients on the cyclicality measures are negative, implying that states with more counter-cyclical expenditures have higher average growth rates. The magnitude of this effect, though, is somewhat smaller than when we include both local and state expenditures. Lastly, the impact of cyclicality on growth is significant at the $10 \%$ level when instrumenting cyclicality with the ACIR index. These results can be seen in Table A4 in the appendix. This extension implies that our conclusions drawn from our main regressions do not hinge on whether we combine state and local expenditures. 
Table 1: Year of Adoption of State Budget Restrictions

\begin{tabular}{cccc}
\hline State & Year & State & Year \\
\hline Alabama & 1867 & Nebraska & 1866 \\
Alaska & 1958 & Nevada & 1864 \\
Arizona & 1867 & New Jersey & 1844 \\
Arkansas & 1934 & New Mexico & 1911 \\
California & 1849 & New York & 1846 \\
Colorado & 1876 & North Carolina & 1936 \\
Florida & 1885 & North Dakota & 1889 \\
Georgia & 1877 & Ohio & 1851 \\
Hawaii & 1959 & Oklahoma & 1907 \\
Idaho & 1889 & Oregon & 1857 \\
Illinois & 1848 & Pennsylvania & 1857 \\
Indiana & 1851 & Rhode Island & 1842 \\
Iowa & 1846 & South Carolina & 1868 \\
Kansas & 1855 & South Dakota & 1889 \\
Kentucky & 1850 & Texas & 1845 \\
Louisiana & 1845 & Utah & 1895 \\
Maine & 1848 & Virginia & 1870 \\
Maryland & 1851 & Washington & 1889 \\
Michigan & 1843 & West Virginia & 1872 \\
Minnesota & 1857 & Wisconsin & 1848 \\
Missouri & 1875 & Wyoming & 1889 \\
Montana & 1889 & & \\
\hline
\end{tabular}

Source: Savage (1988). 
Table 2: Comparing means across ex-post $=1$ and ex-post $=0$

\begin{tabular}{lrrrr}
\hline & All states & Ex-post $=0$ & Ex-post $=1$ & \multicolumn{1}{c}{ Difference } \\
\hline Nominal growth rate & $5.96 \%$ & $6.04 \%$ & $5.93 \%$ & $0.11 \%$ \\
Real growth rate & $1.89 \%$ & $1.97 \%$ & $1.86 \%$ & $0.11 \%$ \\
Std.dev (growth rate) & $3.88 \%$ & $4.91 \%$ & $3.39 \%$ & $1.52 \% *$ \\
Total expenditure to GSP & $17.31 \%$ & $17.48 \%$ & $17.24 \%$ & $0.24 \%$ \\
Current Operations to Total Expenditure & $72.04 \%$ & $71.34 \%$ & $72.31 \%$ & $-0.96 \%$ \\
Capital Outlays to Total Expenditure & $13.48 \%$ & $11.77 \%$ & $14.14 \%$ & $-2.37 \% * * *$ \\
Health expenditure to total expenditure & $7.28 \%$ & $6.33 \%$ & $7.65 \%$ & $-1.32 \% * *$ \\
Education expenditure to total expenditure & $31.01 \%$ & $28.64 \%$ & $31.93 \%$ & $-3.30 \% * * *$ \\
Real GSP per capita in 1977 & 8.839 & 9.836 & 8.452 & $1.384^{* * *}$ \\
$\quad$ in \$k in 1982-84) & 11.5 & 11.6 & 11.5 & 0.1 \\
Average years of schooling in 1977 & 4381660 & 6906714 & 3399694 & $3507020^{* * *}$ \\
Population in 1977 & $75.5 \%$ & $64.3 \%$ & $80.0 \%$ & $-15.7 \%$ \\
Democrat in 1977 & 2.02 & 2.00 & 2.03 & -0.03 \\
\# switched party in 1977-1997 & $21.1 \%$ & $19.2 \%$ & $21.8 \%$ & $-2.6 \% * *$ \\
Federal IG revenue to Total expenditure & $12.7 \%$ & $15.5 \%$ & $11.7 \%$ & $3.8 \%$ \\
ratio in 1977 & 50 & 14 & 36 & \\
Total debt to GSP ratio in 1977 & & &
\end{tabular}

Note: $*, * *$, and $* * *$ denote significant difference between ex-post $=1$ and ex-post $=0$ at the 10,5 , and 1 percent levels, respectively. 
Table 3: Mean of estimated fiscal cyclicality by expenditure categories

\begin{tabular}{lcccc}
\hline & All states & Ex-post $=0$ & Ex-post $=1$ & Difference \\
\hline Total expenditure & -0.148 & -0.313 & -0.085 & -0.228 \\
& $(0.044)$ & $(0.033)$ & $(0.056)$ & $(0.092)^{* * *}$ \\
Current operations & -0.045 & -0.126 & -0.014 & -0.112 \\
& $(0.035)$ & $(0.038)$ & $(0.044)$ & $(0.074)^{*}$ \\
Salaries & -0.031 & -0.043 & -0.026 & -0.016 \\
& $(0.038)$ & $(0.062)$ & $(0.047)$ & $(0.086)$ \\
Education & -0.008 & -0.091 & 0.024 & -0.115 \\
& $(0.050)$ & $(0.112)$ & $(0.054)$ & $(0.110)$ \\
Health & -0.123 & -0.357 & -0.032 & -0.325 \\
& $(0.103)$ & $(0.229)$ & $(0.111)$ & $(0.227)^{*}$ \\
Capital outlays & 0.298 & 0.111 & 0.371 & -0.260 \\
& $(0.138)$ & $(0.209)$ & $(0.173)$ & $(0.308)$ \\
\hline
\end{tabular}

Note: Standard errors are in parenthesis. * $* *$, and *** denote significant difference between ex-post $=1$ and ex-post $=0$ at the 10,5 , and 1 percent levels, respectively 
Table 4: OLS Growth Regressions

\begin{tabular}{lcccc}
\hline & $(1)$ & $(2)$ & $(3)$ & $(4)$ \\
\hline Cyclicality of total expenditure & 0.000 & 0.000 & 0.000 & 0.000 \\
& {$[0.003]$} & {$[0.003]$} & {$[0.003]$} & {$[0.003]$} \\
Real GSP per capita in 1977 & $-0.002^{* * *}$ & $-0.002^{* * *}$ & $-0.002^{* * *}$ & $-0.002^{* * *}$ \\
& {$[0.000]$} & {$[0.000]$} & {$[0.000]$} & {$[0.000]$} \\
Average years of schooling in 1977 & 0.000 & 0.000 & -0.001 & 0.000 \\
& {$[0.002]$} & {$[0.002]$} & {$[0.001]$} & {$[0.001]$} \\
Population in 1977 & & 0.000 & 0.000 & 0.000 \\
& & {$[0.000]$} & {$[0.000]$} & {$[0.000]$} \\
Democrat in 1977 & & -0.002 & -0.001 & -0.002 \\
& & $0.002]$ & {$[0.002]$} & {$[0.002]$} \\
\# switching party in 1977-1997 & & 0.000 & -0.001 & -0.001 \\
& & $0.001]$ & {$[0.001]$} & {$[0.001]$} \\
Ratio of Federal IG revenue to & & & $-0.066^{* * *}$ & $-0.044 * *$ \\
total expenditure in 1977 & & & {$[0.023]$} & {$[0.021]$} \\
Total Debt to GSP ration & & & & $0.043^{* * *}$ \\
in 1977 & & & & {$[0.013]$} \\
Constant & $0.032^{*}$ & $0.036^{* *}$ & $0.062^{* * *}$ & $0.046^{* *}$ \\
& {$[0.016]$} & {$[0.016]$} & {$[0.017]$} & {$[0.017]$} \\
\hline Observations & 50 & 49 & 49 & 49 \\
\hline
\end{tabular}

Note: Heteroskedasiticity robust standard errors are in brackets. *, **, and *** denote significance of the coefficients at the 10,5, and 1 percent levels, respectively. Columns (2)-(4) exclude Maine because the state had an Independent governor in 1977. 


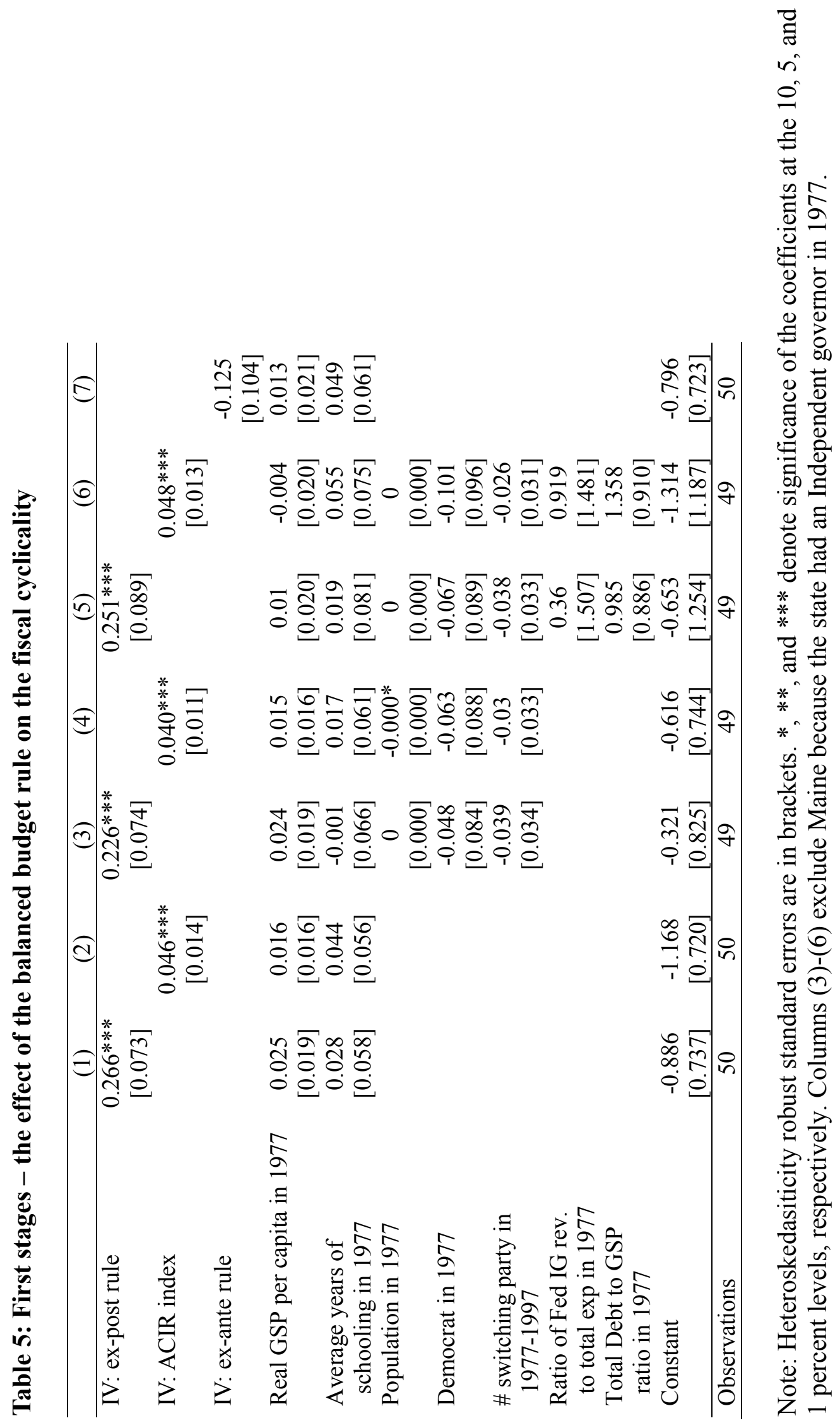




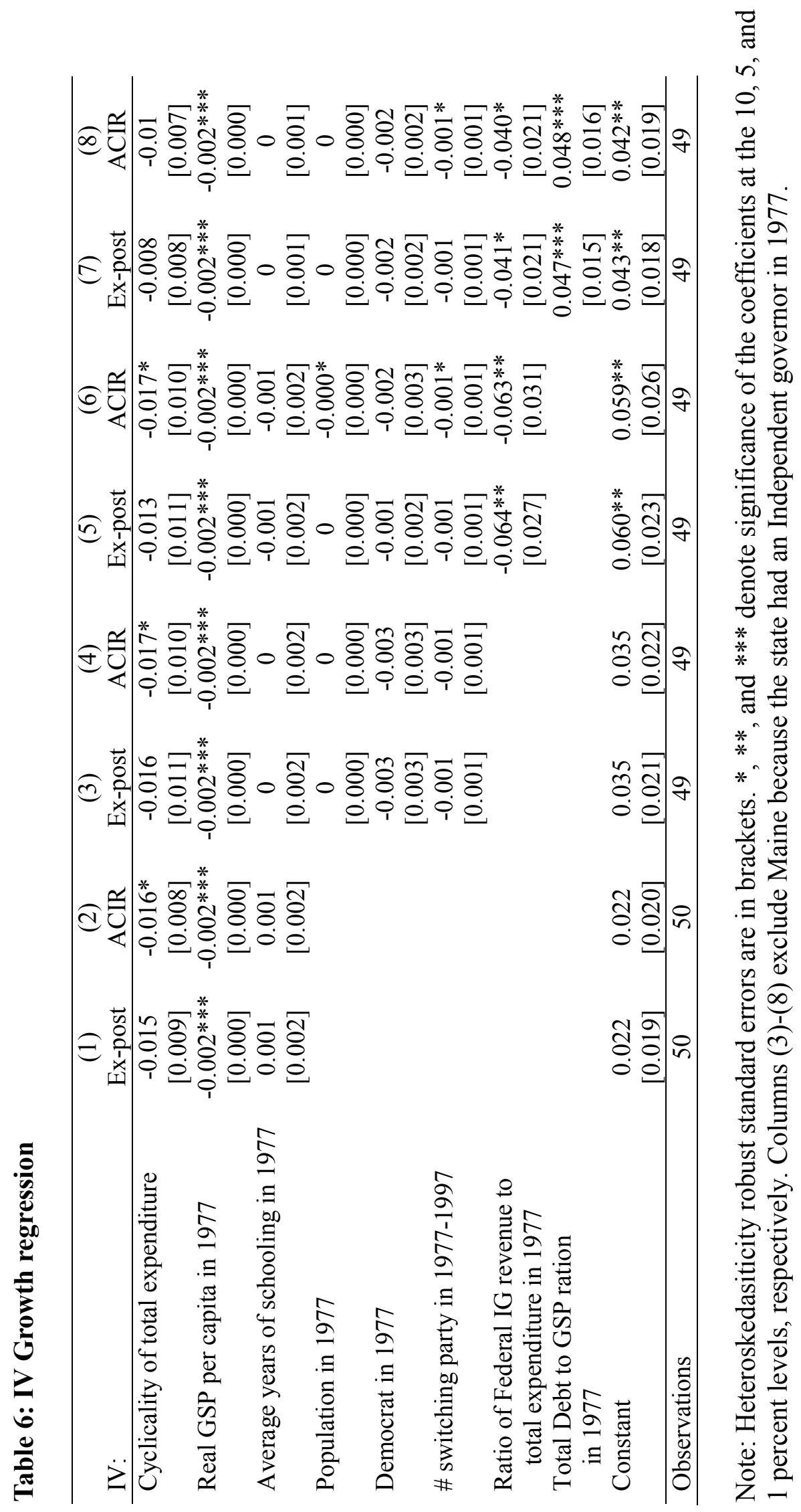


Table 7: Direct effect of introducing ex-post restriction on growth

\begin{tabular}{|c|c|c|c|c|}
\hline & (1) & (2) & (3) & (4) \\
\hline \multirow[t]{2}{*}{ Ex-post rule } & $-0.004 *$ & -0.004 & -0.003 & -0.002 \\
\hline & {$[0.002]$} & {$[0.002]$} & [0.002] & {$[0.002]$} \\
\hline \multirow[t]{2}{*}{ Real GSP per capita in 1977} & $-0.002 * * *$ & $-0.002 * * *$ & $-0.002 * * *$ & $-0.003 * * *$ \\
\hline & {$[0.000]$} & {$[0.000]$} & {$[0.000]$} & {$[0.000]$} \\
\hline \multirow[t]{2}{*}{ Average years of schooling in 1977} & 0 & 0 & -0.001 & 0 \\
\hline & [0.001] & {$[0.001]$} & {$[0.001]$} & {$[0.001]$} \\
\hline \multirow[t]{2}{*}{ Population in 1977} & & 0 & 0 & 0 \\
\hline & & {$[0.000]$} & {$[0.000]$} & {$[0.000]$} \\
\hline \multirow[t]{2}{*}{ Democrat in 1977} & & -0.002 & -0.001 & -0.002 \\
\hline & & {$[0.002]$} & [0.002] & {$[0.002]$} \\
\hline \multirow[t]{2}{*}{ \# switching party in $1977-1997$} & & 0 & -0.001 & -0.001 \\
\hline & & {$[0.001]$} & {$[0.001]$} & {$[0.001]$} \\
\hline $\begin{array}{l}\text { Ratio of Federal IG revenue to } \\
\text { total expenditure in } 1977\end{array}$ & & & $\begin{array}{c}-0.063 * * * \\
{[0.021]}\end{array}$ & $\begin{array}{c}-0.044 * * \\
{[0.020]}\end{array}$ \\
\hline $\begin{array}{l}\text { Total Debt to GSP ration } \\
\text { in } 1977\end{array}$ & & & & $\begin{array}{c}0.039 * * * \\
{[0.013]}\end{array}$ \\
\hline \multirow[t]{2}{*}{ Constant } & $0.035 * * *$ & $0.040 * * *$ & $0.063 * * *$ & $0.048 * * *$ \\
\hline & {$[0.013]$} & {$[0.015]$} & {$[0.016]$} & {$[0.016]$} \\
\hline Observations & 50 & 49 & 49 & 49 \\
\hline
\end{tabular}

Note: Heteroskedasiticity robust standard errors are in brackets. *, **, and *** denote significance of the coefficients at the 10,5, and 1 percent levels, respectively. Columns (2)-(4) exclude Maine because the state had an Independent governor in 1977. 


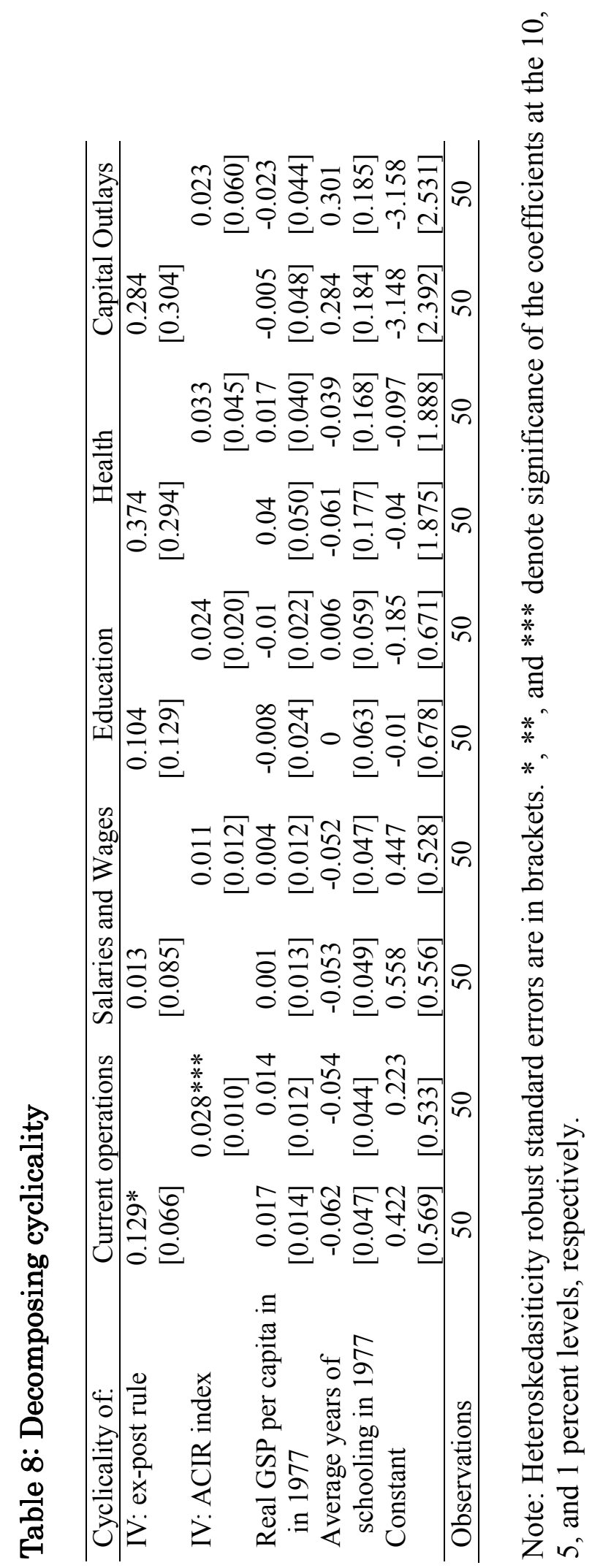




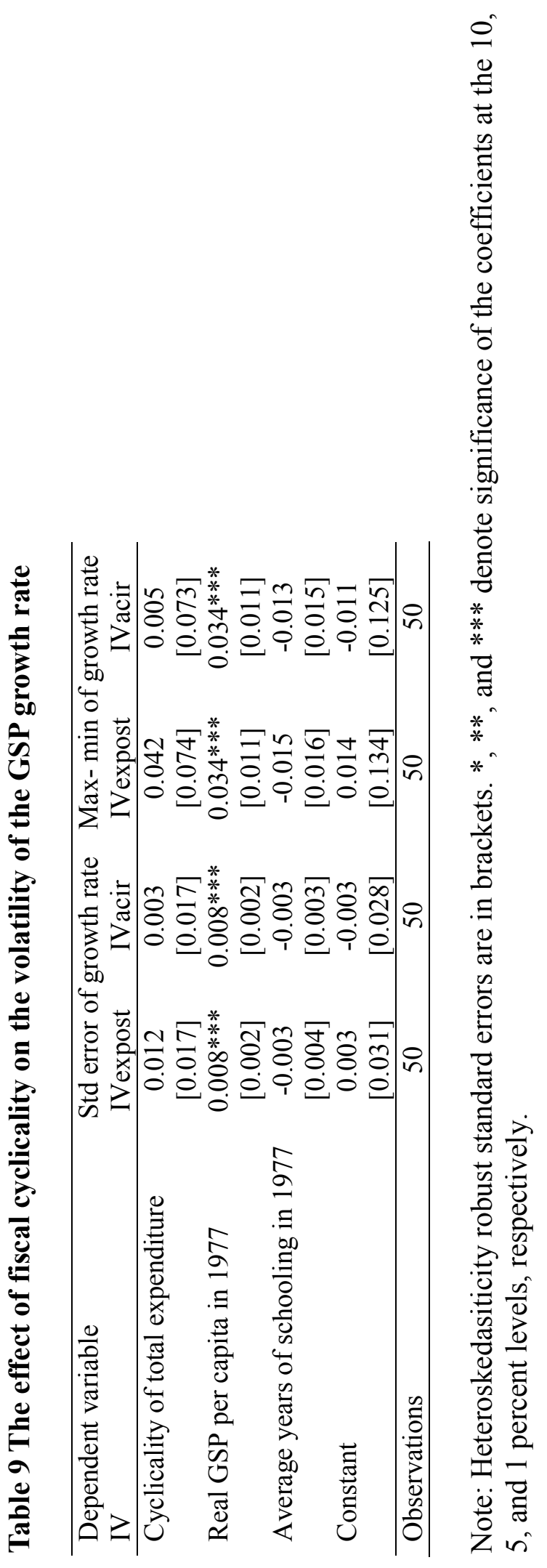




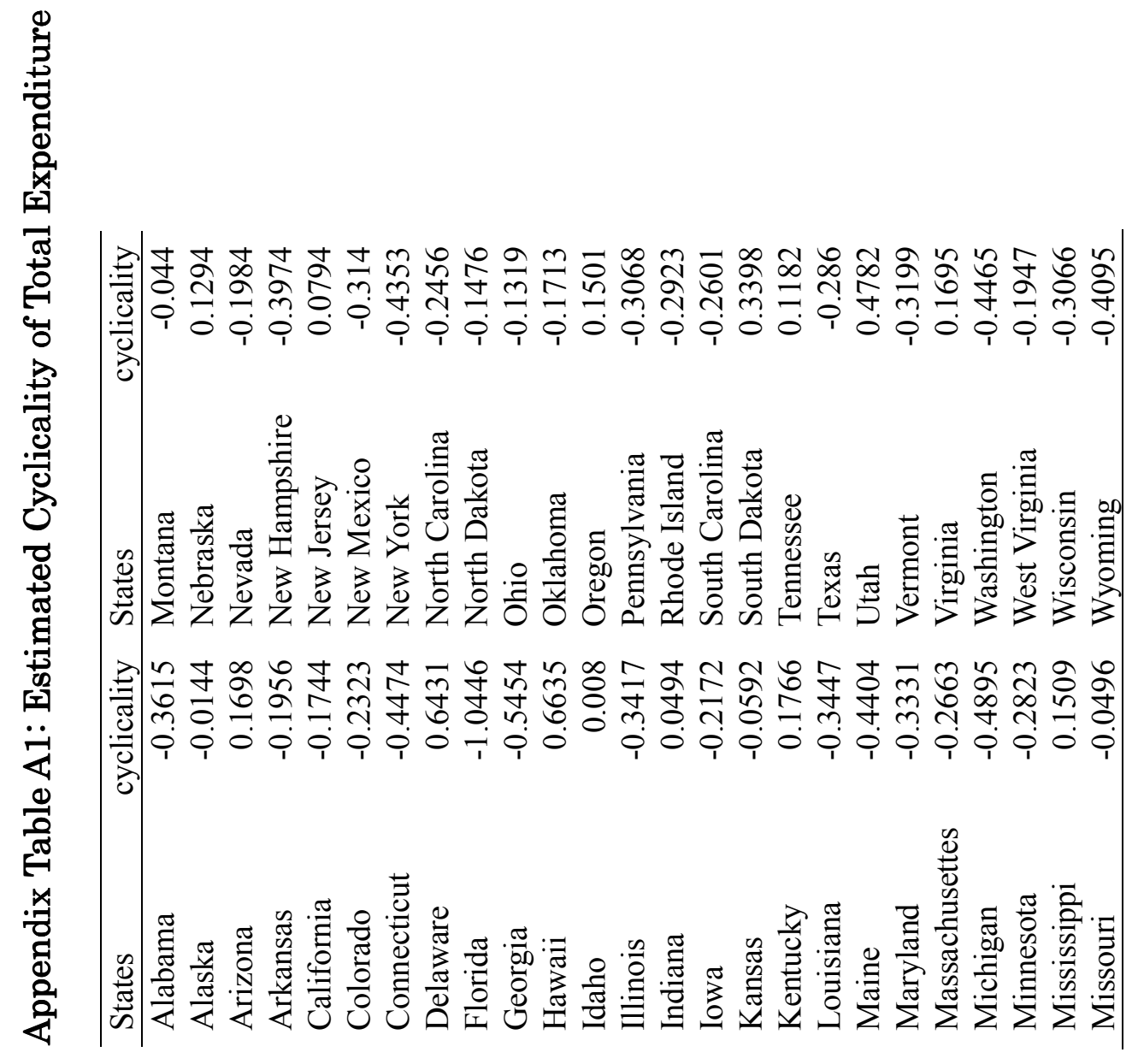




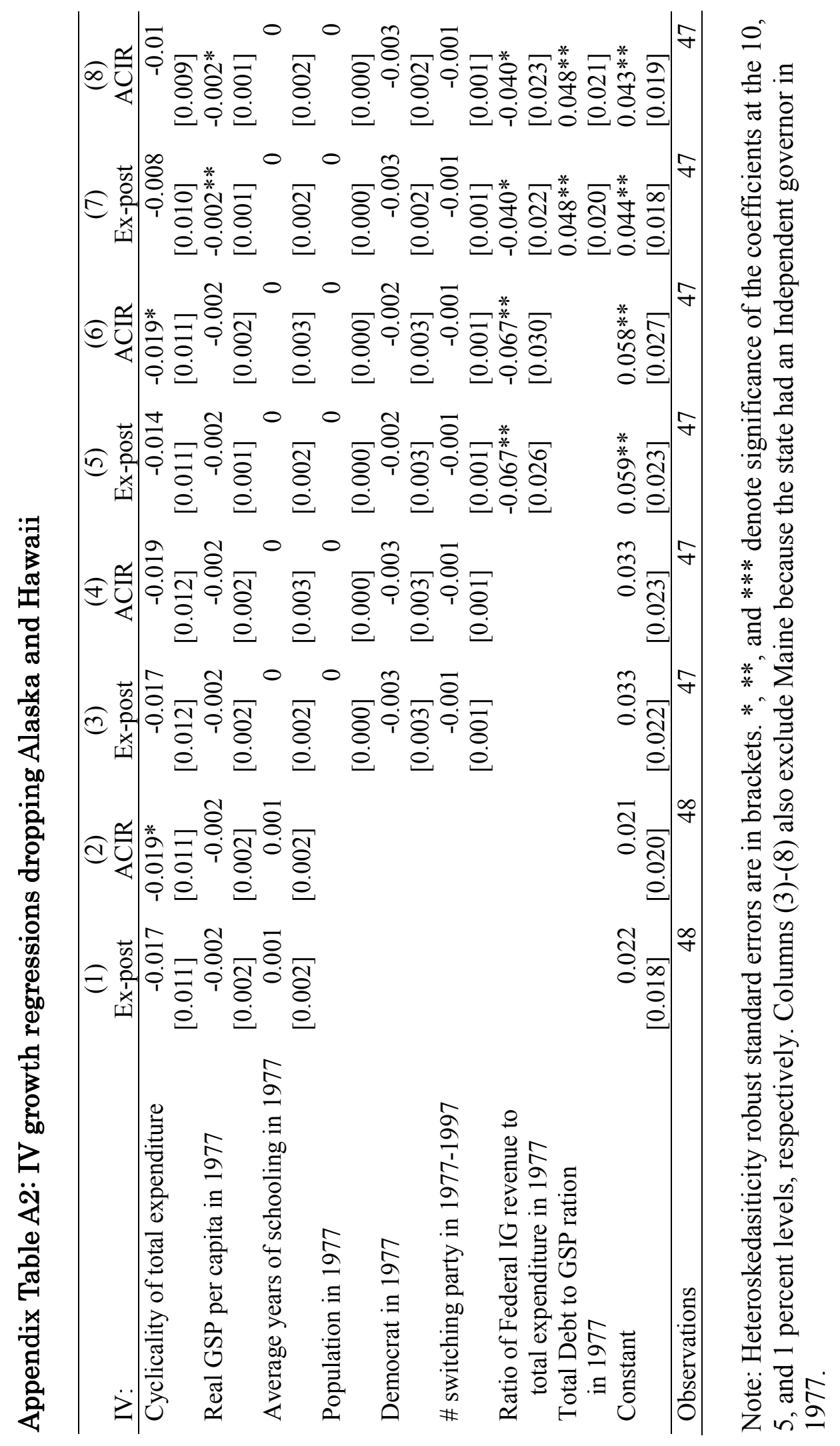




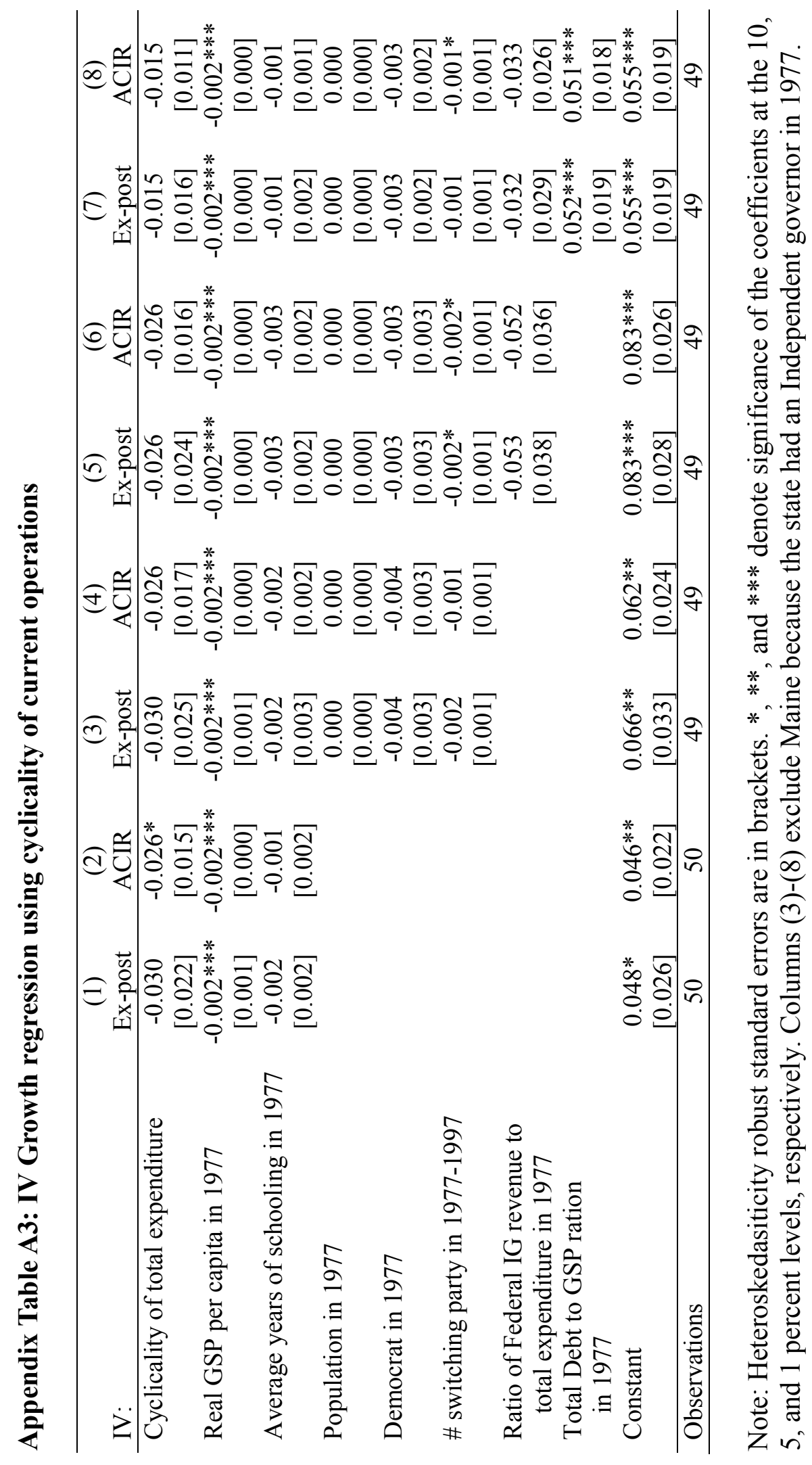




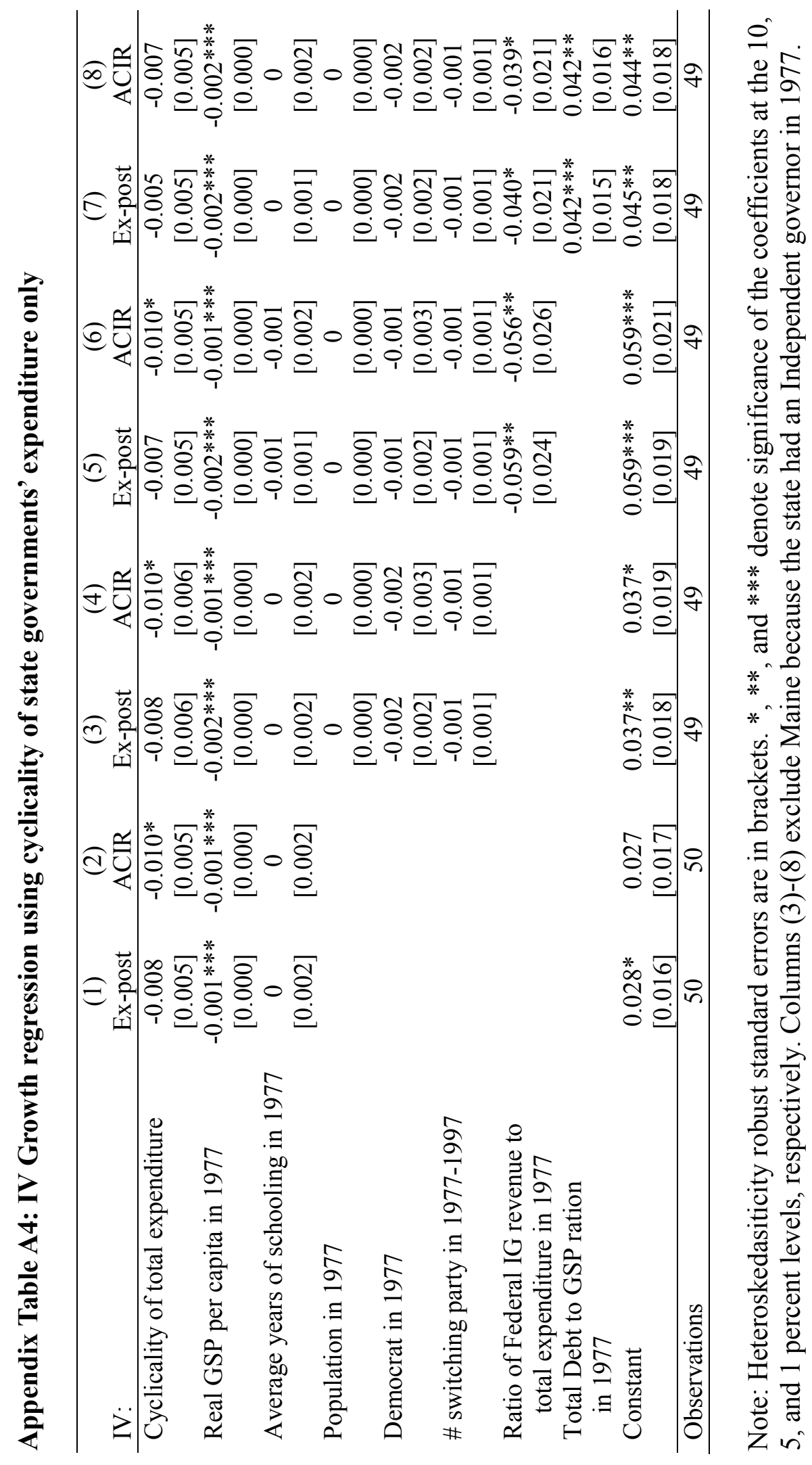

